\title{
ISOLASI DAN KARAKTERISASI JAMUR LIGNINOLITIK SERTA PERBANDINGAN KEMAMPUANNYA DALAM BIODELIGNIFIKASI
}

\author{
Putri Elvira Valencia, VinCENTIA IREne Meitiniarti
}

Fakultas Biologi, Universitas Kristen Satya Wacana, Jalan Diponegoro 52-60 Salatiga 50711

\section{A B S T R A C T}

Fungi can survive in various environments with different media including wood. Lignin in timber is hard to be degraded and hydrolyzed efficiently because of its polymer form, composite and complex structure. Ligninolytic fungi produce an extracellular enzyme to withstand with toxic or mutagenic chemicals exposure and known to degrade different types of pollutant compounds. Lignin decomposers were also known to play a significant role in the pulping process of paper mills, used in waste treatment such as textile and hydrocarbon wastes. This study was conducted to obtain fungal isolates that have delignification capability and to compare the ability of fungal isolates in degrading lignin. Isolates were from rotten wood and soil using selective lignin medium with tannic acid as sole C source. This study characterized the isolates by their morphology and identified them using Morphology and Taxonomy of Fungi book by Bessey (1950). The ligninolytic capability comparison was conducted by measuring the transparent zone formed on selective lignin media. This research found 14 isolates of fungi and all of them had the ligninolytic capability. Aspergillus niger isolate has the highest ligninolytic capability by producing $6.45 \mathrm{~cm}$ clear zone diameter on the 7th day of incubation. Aureobasidium sp. has the smallest clear zone diameter of $1.9 \mathrm{~cm}$ within the same period.

KEY WoRDS: fungi, lignin, biodelignification, ligninolytic, Aspergillus niger, Aureobasidium sp.

Penulis korespondensi: VINCENTIA I MEITINIARTI | email: irene.meitiniarti@staff.uksw.edu

Dikirim: 18-07-2017| Diterima: 25-08-2017

\section{PENDAH UL UAN}

Jamur hidup dan memperoleh nutrisi di berbagai lingkungan, di antaranya pada sisa tumbuhan atau hidup melekat pada organisme lain. Salah satu media yang umum digunakan sebagai tempat tumbuh jamur adalah batang kayu. Jamur yang tumbuh pada batang kayu memiliki kemampuan dalam menguraikan substansi kayu. Jamur kayu dibagi ke dalam 2 kelompok sesuai dengan kemampuannya dalam mengurai substansi kayu, yaitu white rot fungi (mampu menguraikan lignin, selulosa dan hemiselulosa) dan brown rot fungi (mampu menguraikan selulosa dan hemiselulosa) (Artiningsih, 2006).

Lignin merupakan polimer yang tidak mudah diuraikan dan mengandung hydroxycinnamyl alcohols (atau monolignols), coniferil alcohol dan sinapyl alcohol dengan jumlah kecil dari p-coumaryl alcohol (Vanholme et al., 2010). Ikatan yang dapat dihidrolisis hanya sedikit karena strukturnya heterogen dan kompleks. Lignin akan berhubungan dengan ikatan yang berbeda dan senyawa ini terkonsentrasi pada bagian lamella tengah serta lapisan dinding sel yang terbentuk pada proses lignifikasi yang terjadi pada jaringan tanaman (Steffen, 2003). Lignin dapat bertahan terhadap hidrolisis dikarenakan adanya ikatan aril eter yang terdiri dari carbon-oxygen (ether) dan carbon-carbon (C-C) (Parthasarathi et al., 2011). Kandungan lignin sebanyak 30\% dalam tumbuhan menyebabkan tumbuhan kuat terhadap serangan berbagai mikroorganisme (Orth et al., 1993).

Proses dekomposisi lignin baik secara alamiah oleh mikroorganisme sulit dilakukan karena struktur lignin yang sangat kompleks dan kaku. Jamur white rot termasuk ke dalam organisme bersifat ligninolitik yang artinya mampu mendegradasi lignin. Jamur white rot yang tergolong dalam kelompok Basidiomycetes umumnya banyak dijumpai pada substrat kayu. Beberapa jamur yang dilaporkan dapat mendegradasi senyawa lignin yaitu Phanerochaete chrysosporium (Tien \& Kirk, 1983), Trametes versicolor (Roy \& Archibald, 1993), dan Polyporus anceps (Fengel \& Wagener, 1989). Phanerochaete chrysosporium diketahui tiga kali lebih efisien dalam mendegradasi lignin dibandingkan dengan Polyporus sp. (Dey et al., 1994). Phanerochaete chrysosporium merupakan jamur yang paling banyak dipelajari di antara jamur ligninolitik lainnya karena efisien dalam mendegradasi lignin (Howard et al., 2003). Ganoderma applanatum juga dilaporkan memiliki potensi dalam biodelignifikasi (Schlegel \& Schmidt, 1984) yang termasuk dalam golongan Ganodermataceae, Aphyllophorales, Basidiomycetes dan Basidiomycota (Hawksworth et al., 1995).

Jamur white rot sudah banyak digunakan untuk penguraian lignin pada berbagai penelitian seperti Bjerkandera adust a pada inkubasi selama 40 jam dapat mendegradasi lignin hingga $40 \%$ dan mengurangi warna pada lignin sampai $70 \%$. Menurut beberapa penelitian, jamur yang tergolong dalam kelompok white rot tidak hanya dapat menguraikan lignin, namun juga dapat menguraikan berbagai jenis senyawa polutan. Enzim ekstraseluler yang dihasilkan oleh jamur ini menyebabkan jamur dapat bertahan terhadap paparan bahan kimia yang bersifat toksik atau mutagenik seperti DDT, PCB, linden, dioxin dan benzo-a-pyrene (Subowo, 2009).

Teknik biodelignifikasi merupakan salah satu teknik degradasi lignin dengan menggunakan jamur dan ramah lingkungan. Jamur yang digunakan merupakan jamur kelompok white rot yang akan menghasilkan enzim ligninolitik dalam degradasi lignin. Kemampuan jamur ini dalam degradasi juga 
dapat dikembangkan melalui proses bioteknologi untuk degradasi polimer kompleks seperti senyawa xenobiotic, pengurangan warna effluent dan biobleaching dari kraft pulp. Teknik biodelignifikasi dapat diaplikasikan sebagai pengganti teknik sulfat dalam proses pulping yang dilakukan pada pabrik kertas. Biodelignifikasi tergolong lebih murah dibandingkan dengan pemakaian teknik sulfat dalam skala industri (Moreira et al., 2004). Jamur pengurai lignin juga memiliki fungsi lainnya yaitu dapat digunakan dalam pengolahan limbah seperti limbah tekstil dan hidrokarbon. Menurut Abdulla (2007), Trametes hirsuta memiliki enzim laccase yang dapat mengurangi warna dan tingkat toksisitas dari pewarna tekstil serta mampu mendegradasi triarylmethana, indigoid, azo dan pewarna anthraquinon (Subowo, 2009).

Mengingat pentingnya peranan jamur pengurai lignin dalam bidang industri dan pengolahan limbah serta lingkungan, maka penelitian dalam bidang ini terus dikembangkan. Isolasi jamur semakin banyak dilakukan supaya semakin banyak diperoleh jamur yang memiliki kemampuan biodelifgnifikasi.

Penelitian ini dilakukan untuk mendapatkan isolat jamur yang memiliki kemampuan biodelignifikasi serta mengkarakterisasi jenis dan kemampuannya dalam mendegradasi lignin.

\section{E T O D E}

Isolasi jamur dilakukan dengan pengambilan sampel pada kayu dari pohon mangga (Mangifera indica). Kemudian dilakukan pengenceran sampel hingga $10^{-5}$ menggunakan larutan garam fisiologis steril. Dari seri pengenceran $10^{-1}$, $10^{-3}, 10^{-5}$ masing-masing diambil $0,1 \mathrm{ml}$ dengan mikropipet dan ditaburkan pada medium selektif lignin dengan komposisi $1,5 \%$ malt extract, $0,5 \%$ asam tannin dan $2 \%$ agar. Setiap pengenceran dilakukan pengulangan sebanyak tiga kali. Inkubasi dilakukan selama 3-7 hari sampai terbentuk zona jernih. Zona jernih yang terbentuk menandakan adanya jamur yang dapat mendegradasi lignin yang terkandung di dalam media. Kemudian, dilakukan pemurnian isolat jamur dengan menggunakan media PDA.

Karakterisasi isolat jamur dilakukan secara mikroskopik. Pengamatan mikroskopik dilakukan pada isolat jamur yang ditumbuhkan dengan teknik slide culture (Silawati, 2013). Metode slide culture dilakukan dengan alat dan bahan yang terdiri dari gelas objek, batang penahan gelas objek, gelas penutup dan kapas yang telah disterilkan sebelumnya. Media diteteskan secukupnya pada gelas objek kemudian jamur diinokulasikan pada medium. Gelas objek ditutup dengan gelas penutup dan diletakkan di dalam cawan Petri yang diberi kapas dan diberi batang gelas sebagai penahan. Kapas ditetesi sedikit akuades steril dan diletakkan pada bagian kiri kanan gelas objek dalam cawan Petri untuk menjaga kelembapan di dalam cawan Petri. Cawan Petri kemudian dibungkus kertas dan diinkubasi selama 3-5 hari. Identifikasi jamur didasarkan pada karakter morfologi isolat jamur dibandingkan dengan buku acuan berjudul Morphology and Taxonomy of Fungi (Bessey, 1950).

\section{HASIL DAN PEMBAHASAN}

Hasil isolasi dari berbagai sumber, diperoleh 14 isolat jamur yang dapat tumbuh pada medium yang mengandung lignin. Identifikasi jamur dilakukan berdasarkan ciri morfologi yang dapat dilihat pada Tabel 1.

Hasil identifikasi menunjukkan ke-14 isolat jamur tersebut tergolong dalam genus Aspergillus, Penicillium, Trichoderma, Scopulariopsis, Fusarium, dan Aureobasidium. Menurut Adlini (2014), Penicillium sp., Trichoderma sp. dan Aspergillus sp. merupakan jenis jamur yang dapat tumbuh pada media yang mengandung lignin. Penicillium sp. bahkan dapat meningkatkan pertumbuhan tanaman pada tanah gambut karena membantu menyediakan unsur hara bagi tanaman dengan cara mendegradasi sisasisa bahan organik (termasuk senyawa lignin) pada tanah gambut (Yuleli, 2009). Secara keseluruhan, jamur-jamur yang telah diketahui jenisnya termasuk ke dalam Divisi Ascomycota namun tergolong dalam Famili yang berbeda-beda. Aspergillus sp. dan Penicillium sp. yang telah diidentifikasi termasuk ke dalam Famili Trichocomaceae. Kedua genus jamur ini diketahui memiliki kemampuan degradasi lignin yang cukup baik dibandingkan dengan genus jamur lainnya yang juga telah dibuktikan dalam penelitian lainnya (Subowo \& Corazon, 2010). Jamur yang tergolong ke dalam Divisi Ascomycota pada umumnya dapat mendegradasi lignin meskipun dengan kemampuan yang berbeda-beda (Sadhasivam et al., 2008).

Kemampuan mendegradasi lignin akan sangat membantu mengembalikan unsur $\mathrm{C}$ pada bahan organik yang berasal dari tumbuhan, sehingga membantu menyediakan kebutuhan hara tumbuhan (Yuleli, 2009). Aktivitas masing-masing isolat dalam biodelignifikasi dapat diuji dengan menumbuhkan isolat jamur pada medium yang mengandung lignin.

Pada Tabel 2. dapat dilihat perbandingan aktivitas biodelignifikasi, dengan membandingkan ukuran diameter zona jernih yang terbentuk pada masingmasing koloni jamur. Semakin besar ukuran diameter zona jernih maka semakin tinggi aktivitas biodelignifikasi yang dimiliki, begitu juga sebaliknya. Diameter zona jernih jamur diukur pada waktu inkubasi ke-3, 5 dan 7 hari. Berdasarkan hasil yang tertera pada tabel diketahui bahwa seluruh jenis jamur dapat tumbuh pada hari ke-3 dengan diameter zona jernih yang berbeda-beda. Jamur dinyatakan sebagai kelompok penting dalam degradasi bahan organik pada tahap awal, khususnya dalam pengomposan, pada bahan yang mengandung senyawa lignin (Klamer \& Baath, 1998). Pada hasil di atas, kemampuan isolat jamur yang paling besar dalam mendegradasi senyawa lignin adalah Aspergillus niger, diketahui dari ukuran diameter zona jernih terbesar pada penelitian ini yaitu $6,45 \mathrm{~cm}$ pada inkubasi hari ke-7 (Gambar 3). 
Tabel 1. Hasil identifikasi isolat jamur pendegradasi lignin

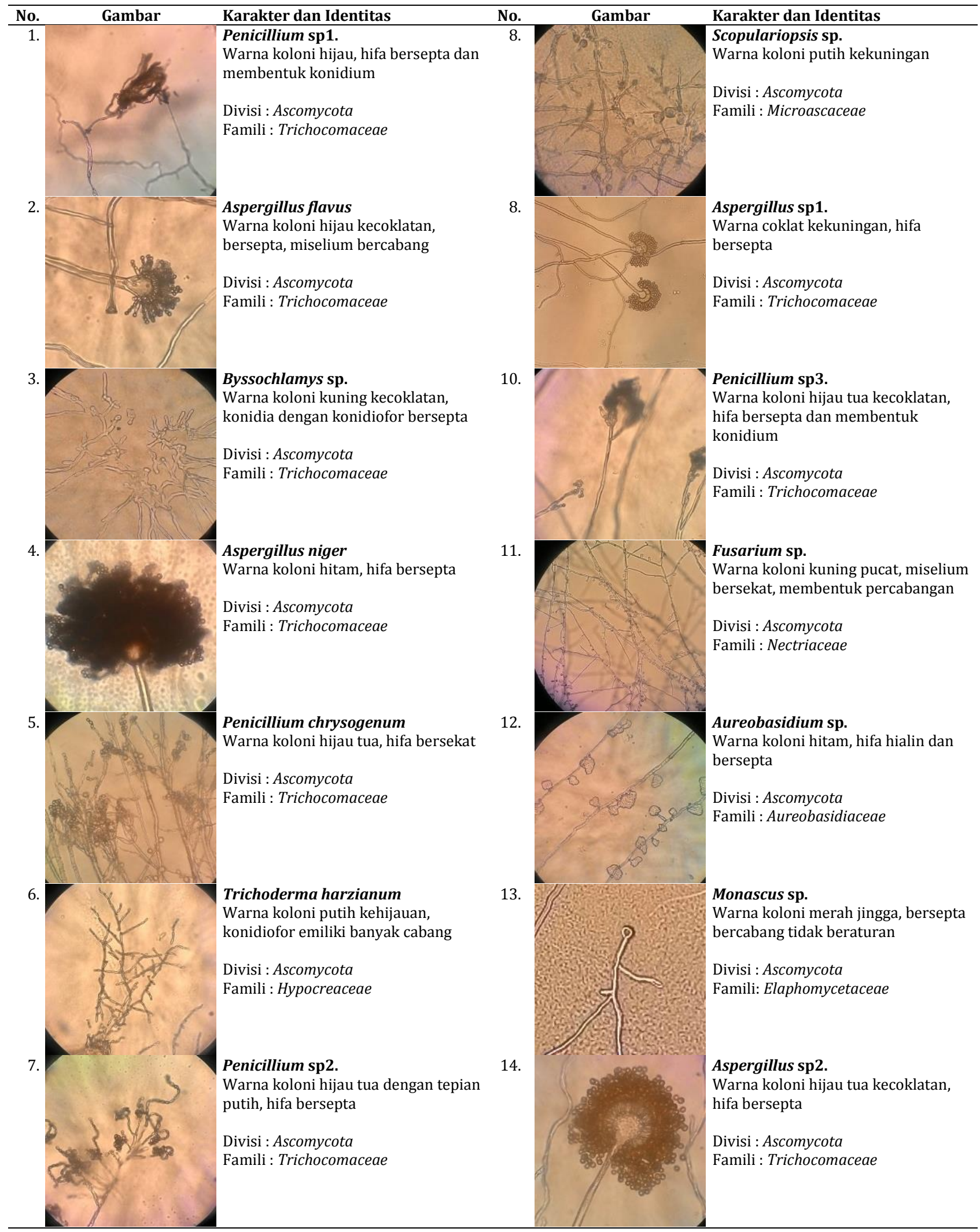

Pada penelitian ini diketahui kemampuan A. niger dalam mendegradasi lignin lebih besar dibanding Penicillium sp. Hal tersebut sesuai dengan hasil penelitian Subowo \& Corazon (2010) serta Subowo (2015) bahwa Aspergillus sp. dan Penicillium sp. memiliki kemampuan mengurai lignin, serta kemampuan $A$. niger lebih tinggi dibandingkan Penicillium sp. Meskipun demikian, Penicillium sp. tetap memiliki kemampuan degradasi lignin yang lebih baik jika dibandingkan dengan jenis jamur lainnya pada penilitian ini. 
Tabel 2. Hasil ukuran diameter zona jernih yang terbentuk pada perbandingan aktivitas biodelignifikasi

\begin{tabular}{lccc}
\hline \multirow{2}{*}{ No. Isolat Jamur } & \multicolumn{3}{c}{ Diameter zona jernih (cm) } \\
\cline { 2 - 4 } & Hari ke- & Hari ke- & Hari ke- \\
& $\mathbf{3}$ & $\mathbf{5}$ & $\mathbf{7}$ \\
\hline 1. Aspergillus niger & 3,15 & 4,75 & 6,45 \\
2. Penicillium sp3. & 1,75 & 2,80 & 3,65 \\
3. Aspergillus sp3. & 1,90 & 2,90 & 3,45 \\
4. Aspergillus flavus & 1,65 & 2,50 & 3,35 \\
5. Scopulariopsis sp. & 1,75 & 2,55 & 3,30 \\
6. Aspergillus sp1. & 1,55 & 2,40 & 3,25 \\
7. Familia : Trichocomaceae & 1,60 & 2,45 & 3,20 \\
8. Penicillium chrysogenum & 1,50 & 2,50 & 3,20 \\
9. Penicillium sp1. & 1,70 & 2,60 & 3,15 \\
10. Penicillium sp2. & 1,65 & 2,40 & 3,15 \\
11. Trichoderma harzanium & 1,35 & 2,20 & 3,00 \\
12. Fusarium sp. & 1,10 & 2,40 & 2,95 \\
13. Familia : Elaphomycetaceae & 1,25 & 2,25 & 2,90 \\
14. Aureobasidium sp. & 0,60 & 1,55 & 1,90 \\
\hline
\end{tabular}

Penicillium sp. memiliki kemampuan degradasi lignin karena menghasilkan enzim ligninase (Yang et al., 2005). Aspergillus sp. lainnya meskipun tidak memiliki kemampuan degradasi lignin sebaik Aspergillus niger, namun dapat mendegradasi lignin karena mampu melakukan metabolisme lignin sebagai sumber karbonnya (Betts \& Dart, 1988).

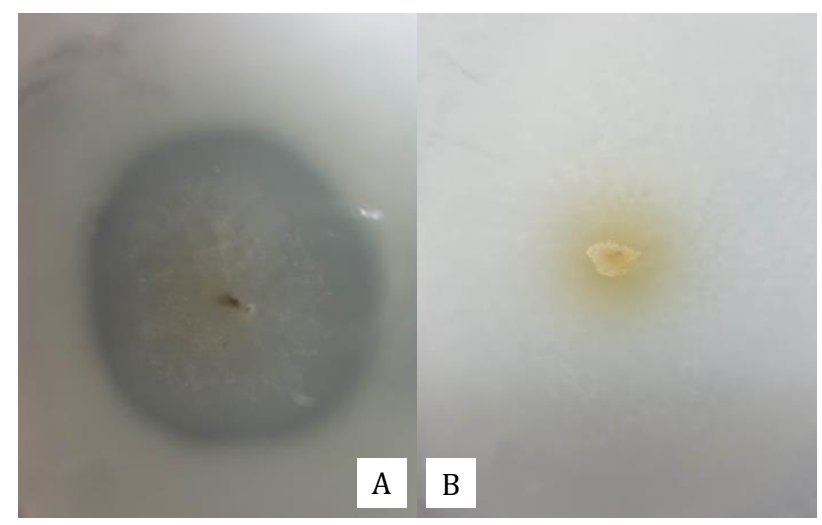

Gambar 3. Zona jernih isolat jamur pada hari ke-3

(A) Aspergillus niger mempunyai zona jernih terbesar

(B) Aureobasidium sp. mempunyai zona jernih terkecil

Proses biodelignifikasi melibatkan berbagai enzim ekstraseluler yang disekresi oleh jamur yaitu lignin peroxidases, manganese peroxidases, versatile peroxidases dan laccases. Laccase merupakan enzim yang mengawali proses oksidasi pada tahap degradasi lignin (Pollegioni et al., 2015). Jamur selain Aspergillus dan Penicillium dapat mendegradasi lignin (Tabel 2.) namun dalam tingkat yang rendah. Jamur yang tergolong dalam kelompok Ascomycetes dalam penelitian ini, yaitu jamur Byssochlamys sp., Monascus sp. dan Trichoderma harzianum diketahui memiliki enzim laccase (Sadhasivam et al., 2008). Pada hasil penelitian diketahui bahwa jamur Aureobasidium sp. adalah jamur yang memiliki kemampuan paling rendah (diameter zona jernih 1,9 cm) dalam mendegradasi lignin (Tabel 2 dan Gambar 3).

\section{K E S I M P U L A N}

Pada penelitian ini diperoleh 14 isolat jamur yang dapat mendegradasi lignin dan termasuk ke dalam Divisi Ascomycota. Isolat jamur yang menunjukkan kemampuan biodelignifikasi cukup besar termasuk dalam familia Trichocomaceae. Di antara ke 14 isolat tersebut, Aspergillus niger merupakan jamur berkemampuan biodelignifikasi paling tinggi dengan diameter zona jernih sebesar 6,45 cm (hari ke-7) sedangkan Aureobasidium sp. adalah jamur berkemampuan biodelignifikasi paling rendah dengan diameter zona jernih 1,9 cm (hari ke-7).

\section{DAFTAR PUSTAKA}

Abdulla HM. 2007. Enhancement of rice straw composting by lignocellulolytic Actinomycetes strains. Int J Agri Biol. 9(1):106109.

Adlini NI. 2014. Seleksi mikroba selulolitik dalam mendegradasi lignin asal tanah gambut Desa Rimbo Panjang Kampar Riau [Skripsi]. [Jurusan Biologi, Fakultas Matematika dan Ilmu Pengetahuan Alam]: Universitas Riau.

Artiningsih T. 2006. Aktivitas ligninolitik jenis Ganoderma pada berbagai sumber karbon. Biodiversitas. 7(4):307-311.

Betts WB, Dart RK. 1988. The degradation of lignin-related compounds by Aspergillus flavus. J Gen Microbiol. 134:24132420.

Bessey EA. 1950. Morphology and taxonomy of fungi. $1^{\text {st }}$ ed. New Delhi: Vikas Publishing House PVT Ltd.

Dey S, Maiti TK, Bhattacharyya BC. 1994. Production of extracellular enzymes by a lignin peroxsidase-producing brown rot fungus, Polyporus ostreiformis, and its comparative abilities for lignin degradation and dye decolorization. Appl Environ Microbiol. $60(11): 4216-4218$.

Fengel D, Wegener G. 1989. Kayu: kimia, ultrastruktur, reaksireaksi. [Terjemahan: H. Sastrohamidjojo]. Jogjakarta: Gadjah Mada University Press.

Hawksworth DL, Kirk PM, Sutton BC, Pelger DN. 1995. Ainsworth and Bisby's dictionary of Fungi. University of Minnesota: CAB International.

Howard RL, Abotsi E, Jansen van Rensburg EL, Howard S. 2003. Lignocellulose biotechnology: issue of bioconvertion and enzyme production. Afr J Biotechnol. 2(12):602-619.

Klamer M, Baath E. 1998. Microbial community dynamics during compositing of straw material studied using phospholipid fatty acid analysis. FEMS Microbiol Ecol. 27(1):9-20.

Lakshmikant. 1990. Cellulose degradation and cellulase activity of five cellulolytic fungi. World J Microb Biot. 6(1):64-66.

Moreira MT, Viacava C, Vidal G. 2004. Fed-batch decolorization of poly R-478 by Trametes versicolor. Braz Arch Biol Techn. 47(2):179-183.

Orth AB, Royse DJ, Tien M. 1993. Ubiquity of lignin peroxidase among various wood-degradation fungi. Appl Environ Microb. 59(12):4017-4023.

Parthasarathi R, Romero RA, Redondo A, Gnanakaran S. 2011. Theoretical Study of The Remarkably Diverse Linkages in Lignin. J Phys Chem Lett. 2(20):2660-2666.

Pollegioni L, Tonin F, Rosini E. 2015. Lignin-degrading Enzymes. FEBS J [Internet]. [cited 2017 August 18], 282(7):1190-1213. Available from https://www.ncbi.nlm.nih.gov/pubmed/25649492.

Roy BP, Archibald F. 1993. Effect of kraft pulp and lignin on Trametes versicolor carbon metabolism. Appl Environ Microbiol. 59(6):1855-1863.

Sadhasivam S, Savitha S, Swaminathan K, Lin FH. 2008. Production, purification and characterization of mid-redox potential laccase from a newly isolated Trichoderma harzanium WL1. Process Biochemistry 43(7):736-742.

Schlegel HS, Schmidt K. 1984. Mikrobiologi Umum. Ed. Ke-6. [Terjemahan: Tedjo Baskoro]. Jogjakarta: Gadjah Mada University Press. 
Silawati, 0. 2013. Pembuatan Slide Culture. [Internet]. [cited 2017 May 25]. Available from: https://www.scribd.com/doc/ 191394145/SLIDE-KULTUR-docx.

Steffen KT. 2003. Degradation of recalcitrant biopolymers and polycycic aromatic hydrocarbons by litter decomposing basidiomycetous fungi. [Desertasi]. University of Helsinki. 69 p.

Subowo YB. 2009. Isolasi dan Seleksi Jamur Aphyllophorales Pengurai Lignin di Hutan Bukit Bangkirai, Kalimantan Timur. Berita Biologi. 9(6):793-797.

Subowo YB, Corazon. 2010. Seleksi Jamur Tanah Pengurai Lignin dan PAH dari Beberapa Lingkungan di Bali. Berita Biologi. 10(2):227-234.

Subowo YB. 2015. Pengujian aktifitas jamur Penicillium sp. R7,5 dan Aspergillus niger NK pada media tumbuh untuk mendukung pertumbuhan tanaman padi di lahan salin. Pros Sem Nas Masy Biodiv Indon. 1(5):1136-1141.
Tien M, Kirk TK. 1983. Lignin-degrading enzyme from the Hymenomycete Phanerochaete chrysosporium Burds. Science. 221(4611):661-663.

Vanholme R, Demedts B, Morreel K, Ralph J, Boerjan W. 2010. Lignin Biosynthesis and Structure. [Internet]. [cited 2017 August 18]. Available from: www.plantphysiol.org/content/153/3/895 doi: https://doi.org/10.1104/pp.110.155119.

Yang JS, Yuan HL, Wang HX and Chen WX. 2005. Purification and characterization of lignin peroxidases from Penicillium decumbens P6. World J Microb Biot. 21(4):435-440.

Yuleli. 2009. Penggunaan Beberapa Jenis Fungi untuk Meningkatkan Pertumbuhan Tanaman Karet (Hevea brasiliensis) di Tanah Gambut [Tesis]. Medan: Universitas Sumatera Utara. 